Reprod. Nutr. Dévelop., 1984, 24 (6), 915-926.

\title{
The structure and steroidogenic potential of the developing gonad and interrenals in the tropical oviparous lizard, Calotes versicolor (Daud.)
}

\author{
Shrimati G. GAITONDE, B. Y. M. GOUDER
}

Department of Zoology Karnatak University

Dharwad-580 003, India.

Summary. A histological study of the developing gonads and interrenals in Calotes versicolor from the day of oviposition (stage 27) to 26 days after hatching shows that the interrenal cells differentiated at stage 31 and were only arranged later into cords. The undifferentiated cells of the sex cord regionated to form the cortex and the medulla at stage 32. The eggs hatched 60 days after oviposition, when the embryos were at stage 42 . The sex cord at this stage showed a well-developed cortex in some embryos, while in others the medulla was well-developed. The bipotent gonad differentiated into either a testis or an ovary on day 15 after hatching.

Histochemical localization of steroid dehydrogenases indicated the presence of $\Delta^{5}-3 \beta$ hydroxysteroid dehydrogenase $\left(\Delta^{\mathrm{b}}-3 \beta-\mathrm{HSDH}\right)$ and glucose-6-phosphate dehydrogenase (G$6-\mathrm{PDH})$ in the interrenal cells of stage 27 embryos, while the activity of these enzymes in the gonads appeared 26 days after hatching. 17 $\beta$-Hydroxysteroid dehydrogenase (17 $\beta$ $\mathrm{HSDH}$ ) activity appeared only in the interrenal cells on the day of hatching (stage 42).

These findings suggest that the interrenals developed the ability to synthesize steroids earlier than the gonads and that the morphological differenciation of the sex cord preceded the onset of steroidogenesis in the gonads of $C$. versicolor.

\section{Introduction.}

The development and differentiation of the gonads and interrenals have been studied in vertebrates that can be bred in captivity and from which eggs and embryos of known age can be procured. These vertebrates, i.e. amphibians, birds and mammals have mostly been domestic or laboratory animals. Except for a few lizards and snakes from the temperate zone, reptiles have been very little investigated. Up to now, these studies, limited in scope, have provided little information on several important aspects. It has not yet been established whether the onset of steroidogenesis in each class of vertebrates is a prelude to sex differentiation or whether the opposite is true. Tropical reptiles differ widely from those of the temperate zone in their patterns of reproduction and development. 
Though the steroidogenic function of the gonads and interrenals of temperate zone reptiles is known from a few studies (Botte and Delrio, 1964 ; Chieffi and Botte, 1966 ; Dufaure and Mesure, 1967 ; Morat, 1971; Raynaud and Pieau, 1971), there is little information on this point in tropical reptiles.

The present study describes the differentiation of the urogenital ridge in the embryo of Calotes versicolor into interrenals and a testis or an ovary. The onset of steroidogenesis, steroidogenic cellular sites, and their ability to synthesize C-21, C-18 and C-19 steroid hormones have been determined histochemically.

\section{Material and methods.}

Adult females of the lizard, Calotes versicolor, which had a large belly indicating the presence of oviductal eggs, were collected from areas around Dharwad $\left(15^{\circ} 17^{\prime} \mathrm{N}\right.$ and $\left.75^{\circ} 3^{\prime} \mathrm{E}\right)$, Karnataka State, India during the breeding season. They were housed in rectangular glass aquarium tanks $(75 \times 37.5 \times$ $50 \mathrm{~cm})$ under atmospheric conditions of temperature $\left(29.3^{\circ} \mathrm{C}\right)$, relative humidity $(62 \%)$ and daylength (12.50 hrs).

The lizards were regularly fed on live cockroaches and water was supplied ad libitum. A few gravid females laid eggs in captivity. However, the majority of them died, retaining the eggs in the oviducts. The eggs recovered from these females immediately after death contained embryos in advanced stages of development. Hence, the eggs containing embryos in early stages were taken from the oviducts of gravid females by stripping. The different embryonic stages were sorted out according to Muthukkaruppan et al. (1970) and were studied from the day of oviposition to day 26 after hatching. The hatchlings were kept in small glass aquarium tanks and regularly fed on termites; water was supplied ad libitum.

The eggs of individual clutches were incubated in Petri dishes padded with moist cotton periodically soaked with water. The embryos were carefully dissected out and fixed in Bouin's fluid for histological study. Serial paraffin sections 5 to $7-\mu \mathrm{m}$ thick were cut and stained with Harris haematoxylin-eosin.

The cellular sites of steroid-converting enzymes in the developing gonads and interrenals were determined by the histochemical demonstration of the activities of $\Delta^{5}$-3 $\beta$-hydrosteroid dehydrogenase $\left(\Delta^{5}-3 \beta\right.$-HSDH $), 17 \beta$-hydroxysteroid dehydrogenase (17 $\beta$-HSDH) and glucose-6-phosphate dehydrogenase (G-6-PDH). Embryos at different stages were decapitated and immediately frozen in dry ice vapours at $-52{ }^{\circ} \mathrm{C}$. Transverse sections 12 to $14-\mu \mathrm{m}$ thick were cut serially in a 'Pearse Slee ' cryostat. The unfixed, frozen sections were aerobically incubated at $37{ }^{\circ} \mathrm{C}$ for an hour in the media containing individual substrates specific for $\Delta^{5}$ $3 \beta$-HSDH and $17 \beta$-HSDH. To demonstrate G-6-PDH activity, the incubation was arrested after 15 to $20 \mathrm{~min}$. The preparation of the incubation media and other details of protocol have already been described (Baillie et al., 1966a ; Gouder and Nadkarni, 1979). The sections were fixed in neutral $10 \%$ formalin for 6 hrs, washed in dimethyl formamide (DMF) or acetone to remove the artifacts due to lipid droplets and crystal deposits and then mounted in glycerol jelly after washing 
thoroughly in distilled water. The extent of the deposition of dark blue diformazan granules was taken as the index of the intensity of enzyme activity and visually assessed (table 1).

\section{Results.}

Histology.

The embryo of C. versicolor developed early when the egg was still in the oviduct. Stages 1 to 26 occurred in the oviductal eggs prior to oviposition. Oviposition usually took place when the embryo was at stage 27. Hatching occurred at embryonic stage 42.

Stages 27 to 30 . - The sections through the caudal half of the stage 27 embryo showed a few mesonephric tubules extending from the posterior part of the lung buds to the caudal limit of the coelomic cavity (fig. 1). The primordial cells of the gonad and interrenals (PCGI) formed a thickened layer at the ventromedian portion of the mesonephric kidney. The PCGI remained virtually undifferentiated so that the gonadal cells could not be distinguished from the interrenal cells at this stage. The thickness of the gonadal interrenal blastema increased by several layers during stages 28,29 and 30 .

\section{TABLE 1}

$\Delta^{5}-3 \beta-H S D H, 17 \beta-H S D H$ and G-6-PDH activities in the developing interrenals and gonads of $\mathrm{C}$. versicolor from the day of oviposition to day 26 after hatching.

\begin{tabular}{|c|c|c|c|c|c|}
\hline \multirow[t]{2}{*}{ Embryonic stages } & \multicolumn{2}{|c|}{$\Delta^{5}-3 \beta-\mathrm{HSDH}$} & \multicolumn{2}{|c|}{$17 \beta-\mathrm{HSDH}$} & \multirow{2}{*}{$\begin{array}{c}\text { G-6-PDH } \\
\text { Disodium salt } \\
\text { of D. glucose }\end{array}$} \\
\hline & DHEA & Pregnenolone & Testosterone & $17 \beta$-estradiol & \\
\hline \multicolumn{6}{|l|}{ Interrenals } \\
\hline 27 & + & \pm & - & - & + \\
\hline 30 & ++ & $\overline{+}$ & - & - & \pm \\
\hline 32 & + \pm & + & - & - & ++ \\
\hline 35 & $+\overline{+}$ & + & - & - & ++ \\
\hline 38 & +++ & + & - & - & ++ \pm \\
\hline 41 & +++ \pm & ++ & - & - & +++ \pm \\
\hline Day 1 after hatching & $++t \bar{t}$ & +++ & ++ & ++ & ++++ \\
\hline Day 15 and 26 after hatching & +++++ & +++ & ++ \pm & ++ \pm & $++t+$ \\
\hline \multicolumn{6}{|l|}{ Gonads } \\
\hline $\begin{array}{l}\text { Stage } 27 \text { to day } 15 \text { after } \\
\text { hatching }\end{array}$ & - & - & - & - & - \\
\hline \multicolumn{6}{|l|}{ Day 26 after hatching } \\
\hline a) Testis & + & + & - & - & + \\
\hline b) Ovary & + & + & - & - & + \\
\hline
\end{tabular}

The intensity of the reactions was judged by diformazan granule deposition which varied between ++++ (maximum) and + (minimum). Traces : \pm ; no reaction : - . The fine, analytical grade chemicals used in the study were obtained from Sigma Chemical Compagny, USA. 
Stages 31 and 32. - The cells from the anterior region of the PCGI separated out to form the interrenal gland, the remaining thickened posterior region, hanging down the ventromedian side of the mesonephric kidney, formed the sex cord at stage 31. At stage 32, a few large cells in the periphery of the sex cord having big nuclei with distinct nucleoli and a clear nuclear membrane formed the cortex (fig. 2). The small inner cells formed the medulla of the sex cord. The cortical cells at this stage were in a single layer, while the medulla contained a number of closely packed cells.

Stages 33 and 34. - The interrenal gland was clearly delineated from the adjoining sex cord during stages 33 and 34 . The cells showed a tendency to arrange themselves into cords. The cortical celis multiplied to form 2 to 3 layers. The medullary region was larger than the cortex.

Stages 35 to 42 . - The interrenal celis increased in number and were arranged in cords. The cortical portion of the sex cord encapsulated the medulla on the ventral side of the latter. The eggs hatched at stage 42 .

Day 1 after hatching. - The sex cord still contained both the cortex and the medulla (fig. 3). However, the medulla in some embryos was well developed showing a tendency to maleness, while in others with a well-developed cortex the tendency was to femalesness.

Days 15 and 26 after hatching. - A marked change in gonadal development occurred on day 15 after hatching. Sexual differentiation into a male (only the medulla well-developed) or a female (only the cortex well-developed) took place. The medulla in the males formed the testis and the cortex in the females formed the ovary. Degenerating medulla cells persisted in the female hatchling (fig. 4), while in the male the cortex disappeared completely. The cortical cells in the female were large and multilayered and formed the germ bed (figs. 4, 5). The primordial ovarian follicles appeared as nests, showing one or two large cells in the germ bed surrounded by small cells. In males, the testes showed small

FIG. 1. - Cross-section of a stage 27 embryo showing an anlage of gonadal and interrenal cells (arrows). NC : nerve cord ; NCH : notochord ; $\mathrm{K}$ : kidney ; $\mathrm{G}$ : gut.

Scale line : $100 \mu \mathrm{m}$

FIG. 2. - Cross-section of a stage 32 embryo. The enlarged sex cords are differentiated into an outer cortex (C) of big cells and an inner medulla (M) of small cells. The interrenal cells (arrow) have separated from the sex cord.

Scale line : $100 \mu \mathrm{m}$

FIG. 3. - Cross-section of the sex cord of a 1-day old C. versicolor hatchling. The cap-like cortex (C) covers the enlarged medulla (M).

Scale line : $20 \mu \mathrm{m}$

FIG. 4. - Cross-section of the sex cord of a 15-day old female hatchling. The medulla is regressed and the cortex has developed into an ovary. GB : germ bed; 00 : oocyte.

Scale line : $50 \mu \mathrm{m}$

FIG. 5. - A magnified view of figure 4 showing the germ bed (GB) and the oocyte (00).

Scale line : $20 \mu \mathrm{m}$

FIG. 6. - Cross-section of the sex cord of a 26-day old male hatchling. The seminiferous cords contain germ cells and Sertoli cells (S) with triangular nuclei. Note the presence of Leydig cells in the interstitium (I). 
interstitial cells amidst the seminiferous cords (fig. 6). These cords appeared solid as their lumen was packed with germ cells, some of which formed mitotic figures. Close to the parietal layer of cords, Sertoli cells with characteristic triangular nuclei were seen (fig. 6).

\section{Histochemistry.}

$\Delta^{5}-3 \beta$-HSDH. - Traces of $\Delta^{5}-3 \beta-\mathrm{HSDH}$ activity existed in the PCGI at stage 27 (fig. 7) and increased progressively during the later development of the embryo. We could not determine whether there was any enzyme activity in the cells of the future interrenals or in the anlagen of the gonads as these structures did not differentiate during stages 27 to 30 . However, at stage 31 , enzyme activity was discerned only in the interrenal cells and not in the anlage of the gonad. Thus, it seems likely that the $\Delta^{5}-3 \beta-\mathrm{HSDH}$ activity observed at stages 27 to 30 was in the interrenal cells and not in the gonadal anlage; this activity in the gonadal elements appeared only at day 26 after hatching, when the sex cord had completely differentiated into either a testis or an ovary (fig. 10). The enzyme activity in the ovary was mainly limited to the oocytes and, to a lesser extent, to the cells of the germ bed. However, the diformazan granules indicating enzyme activity were uniformly distributed in the testis of a 26-day old hatchling. Of the two substrates (pregnenolone and DHEA), used in the incubation media to demonstrate $\Delta^{5}-3 \beta$-HSDH activity, DHEA was preferentially utilized at all the stages studied (table 1).

$17 \beta-H S D H .-$ Whereas $\Delta^{5}-3 \beta-H S D H$ activity was present in the interrenals from the day of oviposition (stage 27), the activity of $17 \beta-\mathrm{HSDH}$ did not appear before the day of hatching (fig. 9) and it continued to increase slightly thereafter. The two substrates (testosterone and $17 \beta$-estradiol) used in the incubation media for localizing $17 \beta-\mathrm{HSDH}$ were equally utilized (table 1 ).

G-6-PDH. - G-6-PDH activity was observed in the interrenal cells of the embryo on the day of oviposition; thereafter the activity of this enzyme grandually increased as embryonic development progressed (table 1). The activity of this enzyme in the gonadal elements appeared only after hatching. Thus, the distribution and appearance of G-6-PDH activity in the embryonic testis, ovary and interrenals followed the same pattern as that of $\Delta^{5}-3 \beta-\mathrm{HSDH}$ in those organs.

FIG. 7. - A frozen section of a stage 27 embryo. Weak $\Delta^{5}-3 \beta$-HSDH activity is seen in the interrenal cells (IC). Dehydroepiandrosterone (DHEA) was used as a substrate.

Scale line : $100 \mu \mathrm{m}$

FIG. 8. - Frontal and longitudinal sections of a stage 35 embryo showing $\Delta^{5}-3 \beta-H S D H$ activity in the cells of the interrenal cords.

FIG. 9. - 17ß-HSDH activity in the interrenal cells (IC) of a 1-day old hatchling.

Scale line : $100 \mu \mathrm{m}$

Scale line : $100 \mu \mathrm{m}$

FIG. 10. - $\Delta^{5}-3 \beta-H S D H$ activity in the interrenal cells (IC) and ovary of a 26-day old hatchling. Intense enzyme activity is seen in the interrenal cells, while in the oocytes it is weak. 


\section{Discussion.}

Studies on the sexual bipotency of the developing gonads of Alligator mississipiensis, Sternothermus odoratus (references in Fox, 1977), Emys leprosa (Stefan, 1963), Anolis carolinensis (Forbes, 1956), L. sicula campestris (Marin and Sabbadin, 1959), Anguis fragilis (Raynaud, 1960), Lacerta vivipara (Dufaure, 1966) and Vipera aspis (Dufaure and Gil Alvaro, 1967) indicate that the sex cord in reptiles remains bipotent for different periods of time and differentiates into an ovary or a testis at different stages of embryonic development. The cortex persists as a residue in the testis of the chelonian, Emys leprosa, 12 months after hatching (Stefan, 1963). The cortical region also persists in the embryonic testis of the lizards, Anolis carolinensis (Forbes, 1956), L. sicula campestris (Marin and Sabbadin, 1959) and Anguis fragilis (Raynaud, 1960). On the other hand, the gonad in Lacerta vivipara (Dufaure, 1966) and Gongy/us ocellatus (Mendietta, 1963) remains bipotential for only a very brief period prior to hatching. Precocious sexual differentiation occurs in the snake. Thamnophis, at 16 to 19 days of incubation (Hartely, 1945). The present study indicates that the embryonic gonad of $C$. versicolor remains bipotent over an extended period, even after hatching, and that this bipotentiality lasts till 15 days after hatching. The cortical region of the male gonad is no longer visible 26 days after hatching, while the female gonad still shows traces of medullary tissue.

The onset of steroidogenic potency in the embryonic gonads appears to vary in different vertebrates. $\Delta^{5}-3 \beta$-HSDH activity in the embryonic gonads of the fishes, Scyliorhinus caniculas, S. stellaris and Torpedo marmorata, has not been histochemically demonstrated, either before or after sex differentiation (references in Yamamoto, 1969). A positive reaction was seen in the interrenals and not in the gonads of the metamorphosing larvae of Rana esculenta (Chieffi and Botte, 1963), while in Pleurodeles waltlii traces of $\Delta^{5}-3 \beta-\mathrm{HSDH}$ were seen in the male sex cord after sexual differentiation (Collenot, 1964). In birds, this enzyme was observed in the undifferentiated gonads of the chick embryo (Woods and Weeks, 1969 ; Scheib and Haffen, 1969), as well as in differentiated gonads at 8 (Narbaitz and Kolodny, 1964 ; Chieffi et al., 1964) and 9 (Boucek et al., 1966) days of incubation. Enzyme activity in the embryonic ovary of the pigeon appears in the medulla and seems to migrate gradually into the cortical region as the embryo grows, while in the testis it appears in the seminiferous cords and later in the interstitial cells (Bhujle et al., 1979). The appearance of steroidogenic potency in the foetal gonads of mammals has been studied in man and in laboratory animals. $\Delta^{5}-3 \beta-H S D H$ activity appears prior to sex differentiation in the genital ridge of the 6-week old human foetus (Baillie et al., 1966b) and on day 11 in the mouse (Baillie, 1965 ; Baillie and Griffiths, 1965). This enzyme appears in the foetal testis of the rat at $\mathbf{1 5 . 5}$ days of gestation, but not in the ovary until 8 to 9 days after birth (Schlegel et al., 1967). Rabbit foetal testes, but not the ovaries, can synthesize testosterone and androstenedione from pregnenolone from day 18 of gestation (Lipsett and Tullner, 1965).

The presence of $\Delta^{5}-3 \beta-H S D H$ activity in the embryonic interrenals of $C$. versicolor as early as stage 27 indicates the potency of these cells to synthesize 
steroids as this enzyme is known to convert $\Delta^{5}-3 \beta$-hydroxysteroids to $\Delta^{4}-3$ ketosteroids, a major step involved in the early synthesis of biologically active steroid hormones (Baillie et al., 1966a). The gradual increase in the intensity of enzyme activity in the interrenals, concomitant with the development of the embryo of this oviparous tropical lizard, is similar to that in the viviparous lizard, Lacerta vivipara (Dufaure and Mesure, 1967; Morat, 1969), of the temperate zone.

$17 \beta-\mathrm{HSDH}$, involved in the synthesis/conversion of sex steroids, is known to oxidize $17 \beta$-hydroxysteroids to 17 -ketosteroids. The appearance of $17 \beta$-HSDH activity in the embryonic interrenals indicates that the potency of these cells to synthesize utilize sex steroids begins on the day of hatching.

The low $\Delta^{5}-3 \beta$-HSDH activity in the embryonic ovary and testis after sex differentiation has already been reported in earlier studies on Lacerta vivipara (Dufaure and Mesure, 1967 ; Morat, 1971) and Lacerta sicula (Botte and Delrio, 1964 ; Chieffi and Botte, 1966). This enzyme appears in the ovarian medulla, while in the testis it is found first in the cords and subsequently in the interstitial cells. However, in the present study on $C$. versicolor, the enzyme activity in the embryonic ovary was mainly found in the oocyte ooplasm and to some extent in the cells that formed the germ bed. The steroidogenic potency of the oocytes and the mature follicles of this reptile have already been reported (Gouder and Nadkarni, 1976). On the contrary, the testis showed a uniform distribution of diformazan granules, indicating that enzyme activity was present throughout the medullary region. The occurrence of G-6-PDH activity, observed in the present investigation in the interrenals and the differentiated gonads, provides additional evidence of the steroidogenic potency of these organs. This enzyme catalyses the synthesis of the nicotinamide adenine dinucleotide phosphate (NADPH) needed for the hydroxylation of steroids during many biosynthetic steps (Weist and Kidwell, 1969).

Our observations reveal that the interrenals are steroidogenically potent as early as the day of oviposition and that the ability to synthesize sex steroids is achieved only after hatching. The ability of the developing ovary or testis to utilise $\mathrm{C}-21$ steroids, as indicated by the presence of $\Delta^{5}-3 \beta-\mathrm{HSDH}$, appears only at day 26 after hatching.

Our observations on the differentiation of embryonic gonads into a testis or an ovary prior to the onset of steroidogenic potency corroborates well with earlier studies on Lacerta vivipara (Dufaure and Mesure, 1967 ; Morat, 1971) and Lacerta sicula (Botte and Delrio, 1964 ; Chieffi and Botte, 1966) which reported that morphological differentiation of the gonad preceded steroidogenesis. Therefore, it appears that some factor(s) other than steroids may be responsible for the differentiation of the gonads in reptiles. However, the role of sex steroids (synthesized by the interrenals) in the differentiation of the gonads in $C$. versicolor cannot be ruled out before it is ascertained by quantification of blood steroid hormones. Sex steroid biosynthesis in birds occurs in the embryonic gonads prior to differentiation (Wolff et al., 1966 ; Weniger, 1968). Though reptiles are the forerunners of birds, the mechanism of sex differentiation is not similar in the 
two groups. Hence, no generalization can be extended to all vertebrates (Haffen, 1977), and the significance of variation in the sex differentiation of vertebrates needs to be elucidated.

Recu en février 1984. Accepté en juillet 1984.

Acknowledgements. - The post-doctoral research fellowship (CSIR, New Delhi) and the gift of fine chemicals from WHO (Geneva, Switzerland) are gratefully acknowledged. This work was supported by Financial Assistance to Teachers Grant No 8916 (UGC, New Delhi). The authors wish to thank Dr. V.B. Nadkarni, Professor of Zoology, Karnatak University, Dharwad, for his invaluable suggestions.

Résumé. Structure et potentialité stéroïdogène des gonades et des interrénales au cours du développement chez le lézard tropical ovipare, Calotes versicolor (Daud).

L'étude histologique du développement des gonades et des interrénales chez Calotes versicolor a été réalisée. Elle commence le jour de l'oviposition (stade 27) et se termine 26 jours après l'éclosion. Elle montre que les celluies interrénales se différencient au stade 31 . Leur association en cordons est plus tardive. Les cellules indifférenciées du cordon sexuel se répartissent en cortex et medulla au stade 32 . Les œufs éclosent 60 jours après l'oviposition, lorsque les embryons sont au stade 42. A ce stade le cordon sexuel présente un cortex bien développé chez quelques embryons, tandis que chez d'autres la medulla est dominante. La différenciation de la gonade en testicule ou en ovaire se produit le $15^{\ominus}$ jour après l'éclosion.

L'étude histochimique permet de détecter la $\Delta^{5}-3 \beta-\mathrm{HSDH}$ et la G-6-PDH dans les cellules interrénales des embryons au stade 27. Ces enzymes apparaissent dans les gonades 26 jours après l'éclosion. L'activité $17 \beta$-HSDN n'apparaît dans les cellules interrénales que le jour de l'éclosion (stade 42).

Ces résultats suggèrent que les interrénales sont aptes à synthétiser les stéroïdes plus précocement que les gonades. La différenciation du cordon sexuel précède le début de la stéroïdogenèse dans les gonades de Calotes versicolor.

\section{References}

BAILLIE A. H., 1965. 3 3 -hydroxysteroid dehydrogenase activity in the foetal mouse testis. $J$. Anat., 99, 507-512.

BAILLIE A. H., GRIFFITHS K., 1965. 3 3 -hydroxysteroid dehydrogenase in the foetal mouse Leydig ceils. J. Endrocrinol., 31, 63-66.

BALLIE A. H., FERGUSON M. M., HART D. Mck. 1966a. Developments in steroid histochemistry. Acad. Press, New York.

BAILLIE A. H., FERGUSON M. M., HART D. Mck., 1966b. Evidence of steroid metabolism and possible biosynthesis in the human genital ridge mesenchyme. J. clin. Endocrinol., 34, 1-12.

BHUJLE B. V., NADKARNI V. B., RAO M. A. R., 1979. Steroid synthesizing cells in the embryonic and aduit gonads of the domestic pigeon, Columba livia (Gmelin). Gen. comp. Endocrinol., 38, 153-161.

BOUCEK R. J., GYORI E., ALVAREZ R., 1966. Steroid dehydrogenase reactions in developing chick adrenal and gonadal tissues. A histochemical study. Gen. comp. Endocrinol., 7, 292-303.

BOTTE V., DELRIO G., 1964. Ricerche istochimiche sulla distribuzinone dei 3-e 17 cheto-steroidi el di alcuni enzimi della steroidogenase nell' ovario di Lacerta sicula. Boll. Zool., 32, 191-195. 
CHIEFFI G., BOTTE V.; 1963. Observazioni istochimiche della steroide $3 \beta$-olo-deidrogenasi nell' interrenale e nelle gonadi di girini e adulti di Rana esculenta.Riv. /stochim. Norm. Pathol., 9. 172-174.

CHIEFFI G., BOTTE V., 1966. II differenziamento istochimico dell' interrenale e dei tissue somatici della gonade embrionale di Lacerta sicula. Rend. Acad. Naz. Lincei, 39, 589-592.

CHIEFFI G., MANELLI H., BOTTE V., MASTROLIA L., 1964. II differenziamento istochimico dell' interrenale e dei tissuti somatici della gonade embrionale di pollo: Compartmento delia 3ß-ol-deidrogenasei. Acta embryol. morphol. exp., 7, 89-91.

COLLENOT A., 1964. Mise en évidence histochimique d'une $\Delta^{5}-3 \beta-H S D H$ dans les gonades non différenciées de mâles génétiques de l'urodèle Pleurodeles waltiil. C. R. Acad. Sci. (Paris), 259, 2535-2537.

DUFAURE J. P., 1966. Recherches descriptives et expérimentales sur les modalités et facteurs du développement de l'appareil génital chez le lézard, vivipare (Lacerta vivipara Jacquin. Arch. Anat. micr. Morph. exp., 55, 437-537.

DUFAURE J. P., GIL ALVARO M. C., 1967. Observations sur l'organogenèse de la gonade et ses particularités chez l'embryon de vipère aspic (Vipera aspis L.). C. R. Soc. Biol., 161, 24712473.

DUFAURE J. P., MESURE M., 1967. Données préliminaires sur l'activité steroido-3 $\beta$-ol deshydrogénasique chez l'embryon de Lézard vivipare (Lacerta vivipare Jacquin). C. R. Acad. Sci. Paris, sér. D., 265, 1215-1218.

FORBES T. R., 1956. The development of the reproductive system of a lizard, Anolis carolinensis. Am. J. Anat., 98, 139-157.

FOX H., 1977. The urinogenital system of reptiles, 1-157. In GANS C. and PARSONS T. S., Biology of the reptilia, Vol. 6, Acad. Press, London, New York.

GOUDER B. Y. M., NADKARNI V. B., 1976. Steroid-synthesizing cellular sites in the ovaries of Calotes versicolor (Daud.), Hemidactylus flaviviridis (Ruppell) and Chemaeleon calcaratus (Boulenger) : A histochemical study. Indian J. exp. Biol., 14, 647-651.

GOUDER B. Y. M., NADKARNI V. B., 1979. Histometric and histochemical changes in the seminiferous epithelium, Leydig cells and Sertoli cells in the testis of Calotes versicolor. Biol. Bull. India., 1, 15-22.

HAFFEN K., 1977. Sexual differentiation of the ovary, 69-112. In ZUKERMAN S., WEIR B. J., The ovary, vol. 1. Acad. Press, New York.

HARTELY R. T., 1945. Effects of sex hormones on the development of the urinogenital system in the garter snake. J. Morph., 76, 115-137.

LIPSETT M. B., TULLNER W. W., 1965. Testosterone synthesis by the foetal rabbit gonad. Endocrinology, 77, 273-277.

MARIN G., SABADDIN A., 1959. Sviluppo e differenziamento delle gonadi in Lacerta sicula campestris. Atti Accad. naz. Lincei. Rc. Solen., 26, 59-62.

MENDIETTA L., 1963. Origine e differenziamento della gonade in Gongy/us ocellatus. Monitore Zool. Ital., 70-71, 201-210.

MORAT M., 1969. Contribution à l'étude de l'activité $\Delta^{5}$-3 $\beta$-hydroxy-stéroïde-deshydrogénasique chez quelques reptiles du Massif Central. Ann. Stat. biol. Besse-en-Chandesse, No 4.

MORAT M., 1971. Activité $\Delta^{5}$-3 $\beta$-hydroxystéroide dehydrogénasique en cours de l'organogenèse des glandes génitales et interrénales chez deux reptiles : Lacerta vivipara J. et Vipera aspis $\mathrm{L}$. Ann. Embryol. Morph., 4, 5-17.

MUTHUKKARUPPAN V. R., KANAKAMBIKA P., MANICHAVEL V., VEERARAGHAVAN K., 1970. Analysis of the development of the lizard, Calotes versicolor. I. A. series of normal stages in the embryonic development. J. Morph., 130, 479-489.

NARBAITZ R., KOLODNY L., 1964. $\Delta^{5}-3 \beta$-hydroxysteroid dehydrogenase in differentiating chick gonads. Z, zell. Forsch. Mikroskop. Anat., 63, 612-617.

RAYNAUD A., 1960. Sur la différenciation sexuelle des embryons d'orvet (Anguis fragilis L.). Bull. Soc. Zool. Fr., 85, 210-230.

RAYNAUD A., PIEAU C., 1971. Evolution des canaux de Müller et activité enzymatique de la $\Delta^{5}-3 \beta-$ HSDH dans les glandes génitales chez les embryons de lézard vert (Lacerta viridis Laur.). C. R. Acad. Paris, Sér. D., 273, 2335-2338. 
SCHEIB D., HAFFEN K., 1969. Apparition et localisation des déhydroxy-stéroïde-deshydrogénases $\left(\Delta^{5}-3 \beta\right.$-et $\left.17 \beta\right)$ dans les gonades de l'embryon et du poussin de la caille (Coturnix coturnix japonica). Etude histoenzymologique et comparaison avec le poulet (Gallus gallus domesticus). Gen. comp. Endocrinol., 12, 586-597.

STEFAN Y., 1963. Contribution à l'étude expérimentale de l'intersexualité chez un chélonien, Emys leprosa. Bull. Biol. Fr. Belg., 97, 363-417.

SCHLEGEL R. J., FARIAS E., RUSSO N. C., MOORE J. R., GARDNER L. I., 1967. Structural changes in the fetal gonads and gonoducts during maturation of an enzyme, steroid $3 \beta$-ol dehydrogenase. Endocrinology, 81, 565-572.

WEIST W. G., KIDWELL W. R., 1969. The regulation of progesterone secretion by ovarian dehydrogenase, 295-325. In McKERNS K. W., The gonads, North Holiand Publ. Co., Amsterdam.

WENIGER J. P., 1968. Sur la précocité de la sécrétion d'œestrogènes par les gonades embryonnaires de poulet cultivées in vitro. C. R. Acad. Sci. Paris, Sér. D., 266, 2277-2279.

WOLFF ET., HAFFEN K., SCHEIB B., 1966. Sur la détection et le rôle d'hormones sexuelies dans les jeunes gonades embryonnaires des oiseaux. Ann. Histochim., 11, 353-368.

WOODS J. E., WEEKS R. L., 1969. Ontogenesis of the pituitary gonadal axis in the chick embryo. Gen. comp. Endocrinol., 13, 242-254.

YAMAMOTO Toki-o., 1969. Sex differentiation, 117-175. In HOAR W. S., RANDALL D. J., Fish physiology, Vol. 3. Acad. Press, New York and London. 